Yudita Susanti dan Ursula Dwi Oktaviani. Baraa Nangis Isantuk ... Halaman $244-257$

Jurnal Belajar Bahasa, ISSN 2502-5864, E-ISSN 2503-0329

Volume 3, No. 2, September 2018

\title{
BARAA NANGIS ISANTUK PAINGKO ARUNG: SUNTINGAN TEKS, TERJEMAHAN, STRUKTUR DAN GAYA BAHASA
}

\author{
Yudita Susanti \\ Ursula Dwi Oktaviani \\ STKIP Persada Khatulistiwa Sintang \\ yuditasusanti@yahoo.co.id, ursuladwioktaviani@yahoo.com
}

\begin{abstract}
ABSTRAK
Baraa Nangis merupakan salah satu sastra lisan suku Dayak Tamambaloh. Baraa Nangislsantuk Paingko Arungadalah cerita rakyat yang menceritakan kegigihan Isantuk Paingko Arung dalam mencari harta ke negeri Jawa. Penelitian Baraa Nangis bertujuan untuk menghimpun dan mendokumentasikan teks Baraa Nangis; menerjemahkan Baraa Nangis agar dapat dipahami dan dinikmati masyarakat luas; mengkaji serta mendeskripsikan struktur Baraa Nangis menurut perspektif A. J.Greimas dan kajian gaya bahasa menurut Gorys Keraf. Pendekatan yang digunakan dalam penelitian ini adalah kualitatif. Pengumpulan data menggunakan metode wawancara, perkaman dan pencatatan. Berdasarkan hasil penelitian, struktur aktansiansial dalam cerita Isantuk Paingko Arung meliputi keinginan kakek mejadikan cucunya terkenal (pengirim); Isantuk Paingko Arung dan rombongannya mencari harta ke negeri Jawa (objek); Isantuk Paingko Arung (subjek); kakek, orang tua, Roronga Sonaru, Burung Pikin Apalin, Landook, Ali-Ali Bua Basi, Tingang, Aniyana, Burung Kiung Balunus, Mando, Lotai Raja Cina, Sipang Batang Sintang, Koling, Saladang Ratu Jawa (penolong); Timbul Laut, Ratu Dadari, Raja Kodali Melayu (penentang); dan orang tua, baro, pekerja lainnya (penerima). Struktur fungsional meliputi: mimpi Isantuk Paingko Arung (situasi awal); Isantuk Paingko Arung menikahi Roronga Sonaru dan harta habis (Transformasi tahap uji kecakapan); Isantuk Paingko Arung beserta rombongannya mencari harta ke negeri Jawa (transformasi tahap utama); Isantuk Paingko Arung mengumpulkan banyak harta dari Raja Kodali Melayu (Tranformasi tahap kegemilangan); dan Isantuk Paingko Arung mampu mengganti harta milik orang tuanya dan hidup bahagia (situasi akhir). Kesimpulan dari fungsi aktansial dan fungsional dari cerita Isantuk Paingko Arung yaitu rasa ingin terkenal - menjalankan titah - harta habis - mencari dan menemukan - harta terganti - hidup bahagia.Gaya bahasa dalam penelitian ini yaitu jujur, sopan-santun dan menarik. Gaya bahasa berdasarkan struktur kalimat mengandung gaya bahasa repetisidan eponim.
\end{abstract}

Kata kunci: cerita rakyat, gaya bahasa, strukturalisme A.J. Greimas

\begin{abstract}
Baraa Nangis is one of the Tamambaloh Dayak ethnic oral literatures. Baraa Nangis Isantuk Paingko Arung is a folklore that tells of the persistence of Paingko Arung Isantuk in finding wealth in the land of Java. The Baraa Nangis study aims to collect and document the text of Baraa Nangis; translating Baraa Nangis to be understood and enjoyed by the wider community; study and describe the structure of Baraa Nangis according to the perspective of A. J. Greimas and language style studies according to Gorys Keraf. The approach used in this study is qualitative. Data collection uses interview method, recording and recording. Based on the results of the study, the financial structure in the story of Isantuk Paingko Arung includes grandfather's desire to make his grandson famous (sender); Isantuk Paingko Arung and his entourage looked for treasures to the land of Java (objects); Isantuk Paingko Arung (subject); grandfather, parents, Roronga Sonaru, Pikin Apalin, Landook, Ali-Ali Bua Basi, Tingang, Aniyana, Kiung Balunus, Mando, Lotai Raja of
\end{abstract}


Yudita Susanti dan Ursula Dwi Oktaviani. Baraa Nangis Isantuk ... Halaman $244-257$ Jurnal Belajar Bahasa, ISSN 2502-5864, E-ISSN 2503-0329

Volume 3, No. 2, September 2018

China, Sipang Batang Sintang, Koling, Saladang Queen of Java (helper); Timbul Laut, Ratu Dadari, King of Kodali Melayu (opponents); and parents, baro, other workers (recipients). Functional structures include: dreams of Isantuk Paingko Arung (initial situation); Isantuk Paingko Arung married Roronga Sonaru and the assets were used up (Transformation of the proficiency test phase); Isantuk Paingko Arung and his entourage sought treasure in the land of Java (the main stage transformation); Isantuk Paingko Arung collects many treasures from King Kodali Melayu (Tranformasi stage of glory); and Isantuk Paingko Arung is able to replace their parents' property and live happily (the final situation). The conclusion of the functional and functional function of the story of Isantuk Paingko Arung is a sense of well-known - carrying out the decree - the treasure is gone - finding and finding the treasure is replaced - living happily. Language style in this research is honest, polite and interesting. Language structure based on sentence structure contains the language style of repetition and the eponym.

Keywords: A.J structuralism Greimas, folklore, language style

\section{PENDAHULUAN}

Sastra lisan atau folklor dipandang sebagai rangkaian kesinambungan dari dokumen sejarah yang dijadikan sebagai bukti sejarah; sejarah keberlangsungan hidup suatu suku bangsa sehingga sastra lisan merupakan bagian dari kehidupan sastra yang hidup dan tersebar di daerahdaerah dalam bentuk tidak tertulis. Dengan demikian, memahami sastra lisan dari suku Dayak Tamambaloh berarti memahami dan mengkaji sejarah keberlangsungan hidup suku Dayak Tamambaloh. Salah satu sastra lisan suku Dayak Tamambaloh yang akan dipahami dan dikaji dalam penelitian ini yaitu Baraa Nangis.

Baraa Nangis merupakan salah satu jenis sastra lisan dari suku Dayak Tamambaloh yang berbentuk nyanyian rakyat. Keunikan atau kekahsan Baraa Nangis yaitu penutur yang menuturkan Baraa Nangis tidak menangis dan tidak mengeluarkan air mata tetapi menyanyikan dengan nada yang resitatif. Baraa Nangis berisi doa, nasihat atau wejangan dan certa rakyat. Baraa Nangis dituturkan oleh seorang penutur usia dewasa. Bahasa yang digunakan dalam Baraa Nangis yaitu bahasa Dayak Tamambaloh dengan bentuk puitis sehingga memiliki gaya bahasa yang khas.

Untuk meneliti Baraa Nangis pada suku Dayak Tamambaloh, maka yang harus dilakukan adalah menyajikan teks Baraa Nangis dalam bentuk tulisan. Suntingan teks adalah langkah untuk mengubah data lisan ke bentuk tulisan. Suntingan yang dihasilkan harus mempertahankan keaslian bentuk teks lisan. Penyuntingan teks naskah merupakan kerja yang rumit serta melibatkan interpretasi. Di bidang sastra lisan "Kecerdikkan dan keahlian diperlukan untuk membujuk penyanyi atau pendongeng berbakat untuk menunjukan kebolehan. Lalu diperlukan pula keahlian mereka atau mencatat suara mereka ke dalam tulisan fonetik" (Wellek \& Warren, 2014, hal. 56). Oleh karena itu, penyuntingan teks tetap berpegang pada naskah pengarang yang ada dan tidak merekontruksi teks versi asli.

Penerjemahan membantu orang lain yang tidak memahami Baraa Nangis. 
Yudita Susanti dan Ursula Dwi Oktaviani. Baraa Nangis Isantuk ... Halaman $244-257$ Jurnal Belajar Bahasa, ISSN 2502-5864, E-ISSN 2503-0329

Volume 3, No. 2, September 2018

Dengan adanya penerjemahan terhadap teks Baraa Nangis yang sudah disunting, Baraa Nangis dapat dipahami dan dinikmati oleh masyarakat luas yang berbahasa Indonesia.

Analisis struktur Baraa Nangis berupa struktur aktansial dan fungsional serta analisis gaya bahasa. Analisi struktur meliputi formula dan formulaik serta tema atau kelompok gagasan Baraa Nangis, sedangkan analisis gaya bahasa yaitu penggunaan kata-kata yang indah dan puitis dalam teks Baraa Nangis.

Menurut Hawkes Strukturalisme adalah cara berpikir tentang dunia yang terutama berkaitan dengan persepsi dan deskripsi struktur (Jabrohim, 1996, hal. 9). Tentang strukturalisme dalam penelitian sastra, Prapdopo mengemukakan bahwa satu konsep dasar yang menjadi ciri khas teori strukturalisme adalah adanya anggapan bahwa di dalam dirinya sendiri, karya sastra merupakan suatu struktur yang otonom yang dapat dipahami sebagai kesatuan yang bulat dengan unsur-unsur pembangunnya yang saling terjalin (Jabrohim, 2003, hal. 71).

Greimas mengembangkan teori aktan.Aktan adalah satuan naratif terkecil yang memiliki fungsi tertentu. Fungsi adalah satuan dasar cerita yang menerangkan tindakan logis dan bermakna yang berbentuk narasi. Kelebihan strukturalisme model Greimasyaitu menyajikan tindakan tokoh cerita dari awal sampai akhir secara terperinci, lebih memperhatikan aksi dibandingkan pelaku(Nirwana, Ade, \& Mardi, 2015). Dalam struktur aktan. Ada beberapa unsur yang membangun yaitu subjek sebagai pelaku, objek, pengirim, penerima, penentang atau oposisi, dan pembantu (Susanto, 2012, hal. 127).

Menurut Rimon-Kenan, aktan dapat berupa suatu tindakan, tidak selalu harus manusia melainkan bisa juga nonmanusia(Ratna, 2014, hal. 138). Aktan akan tetap mementingkan alur cerita sebagai penggerak cerita sehingga sebuah cerita yang terdiri dari permulaan, komplikasi dan penyelesaian. Konsep inilah yang digunakan untuk menganalisis Baraa Nangis Isantuk Paingko Arung.

Baraa Nangis memiliki bahasa yang indah dan puitis sehingga menjadikan Baraa Nangis menjadi unik. Wilpert (1969: 738) mengemukakan bahwa gaya bahasa adalah Still ist (Latin Stilus: Schreibgriffel, Schreibweise) im weiteren Sinne die charakteristische, einheitliche Ausdruks-und Gestaltungsweise bei der Prägung die Kunstwerks überhaupt, in der sich ästhetisches Ziel und Gestaltungskraft des Schöpfers vereinen, bedingt durch das individuelle Künstertum des Schöpfers, seine Standesund Volkszugehörigkeit, seine Heimatgegend oder Stammesherkunft, die Geschmacksrichtung der Zeit, Vorbilder, die verwendete form und deren Gesetze und den zugrundege legten Stoff warden (Wilpert, 1969, hal. 738).

Dalam pengertian tersebut, gaya dalam arti luas adalah karakteristik ragam ekspresif dan cara kreatif dalam membentuk karya seni, kreatif dari pengarang, syarat seni individual dari pengarang, kelas dan golongannya, tempat daerah atau asal suku, perasaan, 
Yudita Susanti dan Ursula Dwi Oktaviani. Baraa Nangis Isantuk ... Halaman $244-257$ Jurnal Belajar Bahasa, ISSN 2502-5864, E-ISSN 2503-0329

Volume 3, No. 2, September 2018

model peran, bentuk yang digunakan dan hukum peristiwa yang mendasarinya. Dengan demikian, dapat dismpulkan, bahwa gaya bahasa merupakan cara mengungkapkan pikiran melalui bahasa secara khas yang memperllihatkan jiwa dan kepribadian menulis (pemakai bahasa).

Dalam penelitian ini, gaya bahasa dalam Baraa Nangis akan dikaji menurut Gorys Keraf. Gaya bahasa yang baik adalah gaya bahasa jujur, sopan-santun dan menarik(Keraf, 2009). Gaya bahasa jujur adalah gaya bahasa yang mengikuti aturan-aturan yang baik dan benar dalam bahasa, tidak menggunakan kata-kata kabur dan terarah. Gaya bahasa sopansantun adalah gaya bahasa yang menghormati pembaca dengan memberikan kejelasan struktur gramatikal kata dan kalimat. Gaya bahasa yang menarik adalah gaya bahasa bahasa yang menarik dan layak untuk dinikmati pembaca. Gaya bahasa yang akan dikaji dalam penelitian Baraa Nangis Bahasa Dayak Tamambaloh adalah gaya bahasa yang baik, sopan-santun, dan menarik serta gaya bahasa struktur kalimat menurut Gorys Keraf.

\section{METODE PENELITIAN}

Pendekatan yang digunakan dalam penelitian ini adalah kualitatif. Analisis data dilakukan dengan menggunakan pendekatan kritik teks dan kritik sastra. Kritik teks untuk menyunting dan menerjemahkan teks Baraa Nangis. Kritik sastra untuk menggali muatan makna (content analysis) yang terkandung dalam teks Baraa Nangis.

Subjek penelitian adalah suku Dayak Tamambaloh yang tinggal di Desa Tamao. Informan Bara nangis adalah pemilik Baraa nangis dan memahami Baraa Nangis sehingga dapat membrikan penjelasan tentang Baraa Nangis. Suku Dayak Tamambaloh tersebar di beberapa wilayah di Kecamatan Embaloh Hulu, Kabupaten Kapuas Hulu, Provinisi Kalimantan Barat. Mengingat sebaran suku Dayak Tamambaloh sangat luas, maka penulis fokus hanya pada satu lokasi penelitian, yaitu Desa Tamao. Desa Tamao berjarak $\pm 89 \mathrm{Km}$ dari ibu kota Kabupaten Kapuan Hulu, yaitu Putussibau.

Objek penelitian adalah Baraa Nangis yang dituturkan oleh informan. Sumber data dala penelitian ini ada dua yaitu, data primer dan data sekunder. Data primer adalah data yang diperoleh peneliti secara langsung dari tangan pertama informan melalui wawancara. Data primer dalam penelitian ini adalah penuturan Baraa Nangis berupa bunyi, kata, frasa dan kalimat-kalimat yang digunakan dalam Baraa Nangis. Data sekunder adalah data yang diperoleh secara tidak langsung, berfungsi untuk mendukung data utama dalam penelitian. Data sekuder dalam penelitian ini berupa gambar-gambar yang mendukung penelitian Baraa Nangis.

Teknik pengumpulan data menggunakan wawancara tidak terstruktur, teknik perekaman, teknik pencatatan dan pengarsipan. Teknik wawancara dilakukan untuk mendapatkan informasi tentang Baraa Nangis. 
Yudita Susanti dan Ursula Dwi Oktaviani. Baraa Nangis Isantuk ... Halaman $244-257$ Jurnal Belajar Bahasa, ISSN 2502-5864, E-ISSN 2503-0329

Volume 3, No. 2, September 2018

Informasi yang dimaksud adalah bagaimana proses penuturan Baraa Nangis dan arti kosakata yang digunakan dalam tuturan Baraa Nangis.

Untuk menghimpun Baraa Nangis Dayak Tamambaloh dan menemukan informasi yang mendukung analisis maka digunakan teknik perekaman. Perekaman dilakukan secara terbuka, informan mengetahui apa yang direkam oleh peneliti. Selain itu, untuk menyunting hasil rekaman menjadi bahan tertulis, digunakan teknik catat. Teknik catat untuk mengumpulkan data Baraa Nangis Dayak Tamambaloh terkait dengan cara menarasikan Baraa Nangis serta kolofon. Teks Baraa Nangis yang ditranskipsikan adalah teks asli, kemudian teks asli dan terjemahan dideskripsikan dengan memberi keterangan pada kolofon meliputi keterangan waktu, tempat, pelaku pencatatan.

Pelaku pencatatan adalah informan dan peneliti, keterangan yang dideskripsikan antara lain nama lengkap, umur, kedudukan dalam masyarakat, pendidikan, dan pekerjaan. Terjemahan dapat dipandang sebagai bentuk resepsi yang sekaligus dapat diartikan sebagai kreasi, dan memainkan peran yang sangat penting sebagai inovasi dan merupakan tahap esensial dalam penerimaan norma-norma baru (Teeuw, 2013, hal. 166-167). Hal ini menurut Teeuw sangat diperlukan untuk sastra Indonesia, baik klasik maupun modern, sebagai bahan dasar untuk sejarah sastra yang modern, sekaligus sebagai jembatan bagi pembaca untuk memahami dan menilai secara lebih kuat hasil terjemahan dalam sastra Indonesia.

Penerjemahan menggunakan terjemahan bebas (free translation). Terjemahan bebas dimaksudkan untuk mengetahui makna kata dalam hubungannya dengan kalimat, dan untuk menerangkan makna kias yang ada dalam teks yang bersangkutan (Endraswara, 2009:96). Dalam penelitian ini, teks asli ditampilkan terlebih dahulu kemudian diikuti dengan teks hasil terjemahan. Teks asli dan terjemahannya akan diberi penomoran atau pengkodean untuk mempermudah menganalisisnya. Prosedur analisis data akan dilakukan seperti analisis data folklor yang dikemukakan (Endraswara, 2009, hal. 223).

\section{PEMBAHASAN}

\section{A. Struktur Aktansial}

Berikut struktur aktan dalam cerita Isantuk Paingko Arung berdasarkan konsep Greimas.

\section{1) Pengirim (sender)}

Pada pola ini, yang berperan sebagai pengirim (sender) adalah keinginan almahrum kakeknya untuk membuat Isantuk Paingko Arung menjadi orang terkenal dan akan dikenang oleh keturunannya. Keinginan kakeknya ini tergambar dalam mimipi Isantuk Paingko Arung. Kakeknya ingin membuatnya terkenal dengan menikaihi Roronga Sonaru. Roronga Sonaru seorang dukun dan baru saja menjanda. Apabila akan menikah, Roronga Sonaru harus membuang masa berduka cita dengan membayar adat sedangkan Isantuk 
Yudita Susanti dan Ursula Dwi Oktaviani. Baraa Nangis Isantuk ... Halaman $244-257$ Jurnal Belajar Bahasa, ISSN 2502-5864, E-ISSN 2503-0329

Volume 3, No. 2, September 2018

Paingko Arung harus membayar adat yang banyak karena menikahi seorang janda yang masih berduka. Keinginan kakeknya tersebut terkabul. Isantuk Paingko Arung menikahi Roronga Sonaru sehingga habislah harta orangtuanya untuk membayar adat ke pemangku adat di Sungai Apalin.

\section{2) Objek (object)}

Yangmenjadi objek dalam pola ini adalah harta di pulau Jawa. Akibat pernikahan yang tidak sewajarnya itu, habislah harta orang tuanya Isantuk Paingko Arung. Sebagai anak yang baik, tentu Isantuk Paingko Arung tidak tingggal diam. Bersama dua pasang baro, Landdok dan Ali-Ali Bua Basi, Tingang dan Aniyana, Burung Kiung Balunus, Mando dan pekerja lainnya, Isantuk Paingko Arung pergi ke pulau jawa menemui Raja Kodali Melayu. Raja Kodali Melayu terkenal sangat kaya, memiliki harta benda yang banyak sehingga mereka pun mau bekerja di tempat Raja Kodali Melayu dengan bayaran harta miliknya. Proses pencarian harta tersebut tidak mudah. Isantuk Paingko Arung beserta rombongannya banyak menghadapi rintangan. Namun karena kesaktian dari empat baro yang menemaninya, mereka dapat melewati rintangan dan akhirnya mendapatkan harta yang berlimpah. Raja Kodali pun menghadiahinya sebuah induk emas sebesar bayi.

\section{3) Subjek (subject)}

Subjek dalam pola ini adalah Isantuk Paingko Arung. la adalah seorang raja keturunan bangsawan di sungai Apalin. la tidak memiliki kecakapan seperti rajaraja lainnya. Oleh kakeknya, diubahnyalah Isantuk Paingko Arung menjadi orang terkenal melalui ceritanya mencari harta ke negeri Jawa, tempat Raja Kodali Melayu. Isantuk Paingko Arung seorang yang tekun, ulet dan pantang berputus asa, ahli berhitung dan ahli berdagang. la juga dapat melunakkan hati orang yang keras menjadi baik. Kehadiran baro yang menyertai perjalannya ke negeri Jawa, lambat laun menjadikan Isantuk Paingko Arung menjadi orang yang sakti dan berani. Banyak orang menjadi takut dan tunduk kepadanya bahkan ada yang tidak berani melawannya karena kesaktian yang ia miliki tidak ada tandingannya.

\section{4) Penolong (helper)}

Pada pola dalam cerita ini, yang menjadi penolong yaitu kakek, orang tua, dua pasang baro, Burung Kiung Balunus dan Mando, Lotai Raja Cina, Raja Sipang Batang Sintang, Roronga Sonaru, Saladang Ratu Jawa dan Koling. Penolong-penolong yang ada dalam cerita ini memberikan bantuan akan kehadiran Isantuk Paingko Arung. Kakek menjadi penolong ketika Isantuk Paingko Arung dan keluarganya menjadi miskin akibat seluruh hartanya digunakan untuk membayar adat perkawinannya dengan Roronga Sonaru. Kakek itu yang mempunyai ide supaya ia pergi ke negeri Jawa menemui Raja Kodali Melayu. Kakeknya meminta dua pasang baro menemaninya ketika ia melakukan perjalanan ke negeri Jawa. Kakek Isantuk Paingko Arung sudah meninggal tetapi ia menyampaikan semua ide melalui mimpi Isantuk Paingko Arung. Sebelum berangkat, Burung Pikin Apalin seorang 
Yudita Susanti dan Ursula Dwi Oktaviani. Baraa Nangis Isantuk ... Halaman 244 - 257 Jurnal Belajar Bahasa, ISSN 2502-5864, E-ISSN 2503-0329

Volume 3, No. 2, September 2018

peamngku adat memanggil roh leluhur suapaya menyertai perjalanan Isantuk Paingko Arung. la juga mencari hari baik melalui tanda yang ada dalam hati babi. Mereka boleh melanjutkan perjalanan apabila hati babi bagus. Kehadiran dua pasang baro yaitu Landook dan Ali-Ali Bua Basi, Tingang dan Aniyana sangat membantu perjalanan Isantuk Paingko Arung dalam mencari harta. Baro merupakan siluman harimau dan mereka adalah pesuruh kakeknya. Pada siang hari, wujud mereka menyerupai manusia dan malam hari menjadi batu. Ada kalanya mereka mewujudkan diri menjadi seekor harimau. Dua pasang baro ini memiliki keahlian dan kesaktian. Mereka dapat mengetahui isi hati musuh-musuh Isantuk Paingko Arung dan hal-hal yang akan terjadi di masa mendatang, memiliki kekuatan untuk terbang, mampu meniupkan angin, memiliki kekuatan meringankan badan, dan kebal terhadap senajata tajam. Merekalah yang membantu Isantuk Paingko Arung ketika melakukan perjalanan dan menghadapi banyak rintangan, baik dari Raja Timbul Laut dan Ratu Dadari maupun Raja Kodali Melayu. Selain menolongnya dalam perjalanan, baro itu juga membantu kedua anaknya, Ratungan dan Jangan yang tersesat di Saniuk ketika mencari ibunya. Burung Kiung Balunus dan Mando adalah pekerja (pembantu) Isantuk Paingko Arung. Kehadiran mereka sangat menolong. Ketika melakukan perjalanan ke negeri Jawa, merekalah yang bekerja di kapal dan mengangkut harta milik Isantuk Paingko Arung. Kadangkala, Burung
Kiung Balunus menjadi penasehat bagi Isantuk Paingko Arung. Kemana Isantuk Paingko Arung pergi, mereka tetap mengikuti. Lotai Raja Cina adalah penguasa di negeri Selimbau. Darinya, Isantuk Paingko Arung belajar berhitung dan berdagang sampai ia memiliki keahlian berhitung dan berdagang. Keahlian yang ia miliki ini menjadi kecakapannya dalam menerima tantangan Raja Kodali Melayu. Raja Sipang Batang Sintang adalah raja di negeri Sintang. la seorang raja yang baik dan bijaksana dan menjadi penolong bagi Isantuk Paingko Arung. la meminjamkan kapal layar miliknya untuk digunakan Isantuk Paingko Arung beserta rombongannya pergi ke negeri Jawa mencari harta. Raja Sipang Batang Sintang juga membantu Isantuk Paingko Arung dalam ilmu berlayar sampai akhirnya Isantuk Paingko Arung bisa menahkodai kapal layar itu. Roronga Sonaru merupakan isteri Isantuk Paingko Arung, ia seorang dukun. la menjadi penolong bagi Isantuk Paingko Arung. Dengan menerima lamaran dan mau dinikahi Isantuk Paingko Arung maka terselamatkanlah kehidupan Isantuk Paingko Arung. Andaikan ia menolak lamaran itu, kehidupan Isantuk Paingko Arung tidak akan ada. la tetap menjadi raja biasa. Selain itu, kehadiran Roronga Sonaru menjadi penolong dengan memberinya dua anak laki-laki, Ratungan dan Jangan. Dengan adanya keturunan langsung dari Isantuk Paingko Arung maka mereka akan menjadi pewaris langsung tahta dan harta miliknya. Roronga Sonaru juga menjadi penolong 
Yudita Susanti dan Ursula Dwi Oktaviani. Baraa Nangis Isantuk ... Halaman $244-257$ Jurnal Belajar Bahasa, ISSN 2502-5864, E-ISSN 2503-0329

Volume 3, No. 2, September 2018

ketika Isantuk Paingko Arung cemburu dengan Koling. Andaikan Roronga Sonaru tidak menjelaskan perihal ikan dan Gunsi, pasti akan terjadi perang saudara. Berkat penjelasan Roronga Sonaru, emosi Isantuk Paingko Arung dapat diredam, ia hanya dihukum adat karena sudah berprasangka buruk dan berniat mencelakai orang lain. Saladang Ratu Jawa adalah isteri Raja Kodali Melayu, yang akhirnya ia nikahi juga. Dari pernikahan itu, mereka mempunyai keturunan bernama Songkalang. Alangkah senangnya Raja Kodali Melayu karena ia akan memiliki keturunan dan menjadi pewaris tahtanya. Sebagai ungkapan bahagianya, Raja Kodali Melayu menghadiahi Isantuk Paingko Arung sebuah induk emas yang menyerupai bayi. Semakin kaya dan banyaklah harta Isantuk Paingko Arung ketika pulang dari negeri Jawa. Koling menjadi penolog terakhir dalam cerita ini. Koling merupakan bangsawan di sungai Apalin dan mengetahui selukbeluk adat istiadat setempat.

\section{5) Penentang (opponent)}

Penentang dalam cerita ini yaitu tokoh-tokoh antagonis seperti Raja Timbul Laut, Ratu Dadari dan Raja Kodali Melayu. Raja Timbul Laut dan Ratu Dadari merupakan penguasa lautan. Kekejaman dan kebengisan mereka sangat terkenal ke seluruh pelosok, salah satunya sungai Apalin. Tidak ada seorang pun yang selamat dan dapat melewati daerah kekuasaannya. Akan tetapi, Isantuk Paingko Arung memiliki kesaktian, ia membuat Raja Timbul Laut dan Ratu Dadari menjadi tunduk. Sehingga ketika kepulangan mereka dari negeri Jawa ke sungai Apalin, mereka tidak diganggu bahkan mereka disambut dan dielu-elukan seperti panglima perang yang memenangkan perperangan. Penentang selanjutnya dalam cerita Isantuk Paingko Arung yaitu Raja Kodali Melayu. Raja Kodali Melayu merupakan seorang raja yang berkuasa di negeri Jawa. Kekayaannya sangat banyak dan melimpah ruah. la juga terkenal dengan kebengisanya. Ketika Isantuk Paingko Arung dan rombongannya tiba di pinggir pantai dan ingin bertemu Raja Kodali Melayu, bukan sambutan baik yang mereka terima tetapi tembakan meriam bertupi-tubi ke arah kapal mereka. Namun bola api yang ditembakan tersebut tidak pernah sampai ke kapal mereka dan hanya sampai di tengah lautan saja, berubah menjadi asap putih. Berulang kali para hulubalangnya menembakan meriam sampai amunisi mereka habis. Ujian kedua yang diberikan Raja Kodali Melayu yaitu memerintahkan para hulubalang dan prajuritnya menyerang kapal Isantuk Paingko Arung. Namun, hal itu mampu diatasi. Banyak hulubalang dan prajurit mati sia-sia di tengah lautan. Hanya dengan sekali tiupan, air laut berubah menjadi gelombang besar dan badai. Mereka yang selamat disuruh Isantuk Paingko Arung pulang menemui Raja Kodali Melayu untuk memberitahukan bahwa kedatangan mereka baik. Raja Kodali Melayu pun meminta Isantuk Paingko Arung datang menemuinya. Ketika bertemu, ia meminta Isantuk Paingko Arung untuk memanjat inti kayu pohon Pulang. la ingin menguji kesaktian 
Yudita Susanti dan Ursula Dwi Oktaviani. Baraa Nangis Isantuk ... Halaman $244-257$ Jurnal Belajar Bahasa, ISSN 2502-5864, E-ISSN 2503-0329

Volume 3, No. 2, September 2018

Isantuk Paingko Arung, apabila ia tidak sakti maka ia akan jatuh dan mati.Namun, Isantuk Paingko Arung memiliki ilmu peringan badan. la memanjat inti kayu pohon Pulang dengan santai dan dengan kukunya yang tajam ia mencapai pucuk pohon pulang tanpa kendala apapun. Kemudian ia menjemur Isantuk Paingko Arung di atas potongan bambu Bakuan yang tua selama tujuh hari tujuh malam namun Isantuk Paingko Arung berhasil melewati ujian itu. Raja Kodali Melayu semakin berang. la beranggapan kalau Isantuk Paingko Arung tidak mati maka kekuasaan dan seluruh hartanya akan menjadi milik Isantuk Paingko Arung. Oleh karena itu, ia menyusun siasat baru. la meminta Isantuk Paingko Arung untuk berdagang ke pulau-pulau lainnya, siapa tahu ia tersesat. Apabila ia tersesat di lautan dan kelaparan maka ia akan mati. Isantuk Paingko Arung menerima tugas itu dengan baik. Karena sudah mendapatkan ilmu dari Lotai Raja Cina, ia berdagang dengan cepat. Lebih cepat dari perkiraan Raja Kodali Melayu bahkan ia membawa hasil dagangan yang sangat banyak, membuat Raja Kodali Melayu terkesima. Akhirnya, Raja Kodali Melayu menerima kesaktian Isantuk Paingko Arung dan ia memperkerjakannya di wilayahnya. Setelah lama bekerja dan sudah banyak mengumpulkan harta, Isantuk Paingko Arung beserta rombongan kembali pulang ke sungai Apalin menggunakan kapal milik Raja Sipang Batang Sintang.

6) Penerima (Recever)
Penerima utama dalam pola ini yaitu kedua orang tua Isantuk Paingko Arung. Penerima objek lainnya yaitu baro dan para pekerja Isantuk Paingko Arung. Harta yang dicari dan diperoleh Isantuk Paingko Arung di pulau Jawa akan diberikan kepada orang tuanya, sebagai pengganti harta yang sudah ia gunakan untuk membayar adat ketika menikahi Roronga Sonaru. Ketika ia pulang dari negerinya Raja Kodali Melayu, ia mendapakan banyak harta. Harta itu sebagian ia serahkan kepada orang tuanya, sebagian lagi ia bagi-bagi kepada dua pasang baro yaitu Landdok dan ali-ali Bua Basi, Tinggang dan Aniyana, para pekerjanya seperti Burung Kuiung Balunus dan Mando serta pekerja lainnya. Walaupun harta itu sudah dibagi-bagi, harta Isantuk Paingko Arung masih saja berlimpah.

\section{B. Struktur Fungsional}

Struktur fungsional dalam cerita Isantuk Paingko Arung meliputi Situasi Awal, Tahap Uji Kecakapan, Tahap Utama, Tahap Kegemilangan dan Situasi Akhir. Berikut skema fungsional cerita Isantuk Paingko Arung dan penejelasannya.

\section{1) Situasi Awal}

Mimpi Isantuk Paingko Arung yang bertemu dengan almahrum kakeknya dan menginginkannya menjadi terkenal (dikenang sepanjang masa). la akan terkenal dengan menikahi Roronga Sonaru, dukun di sungai Apalin.

\section{2) Transformasi Tahap Uji Kecakapan}

Isantuk Paingko Arung menikahi seorang dukun,Roronga Sonaru yang 
Yudita Susanti dan Ursula Dwi Oktaviani. Baraa Nangis Isantuk ... Halaman $244-257$ Jurnal Belajar Bahasa, ISSN 2502-5864, E-ISSN 2503-0329

Volume 3, No. 2, September 2018

baru saja kehilangan suami. la menikah dan habislah harta benda milik orang tuanya untuk membayar adat.

\section{3) Transformasi Tahap Utama}

Isantuk Paingko Arung, dua pasang baro (harimau siluman) dan para pekerja pergi ke negeri Jawa mencari harta. la pergi atas izin pemangku adat Burung Pikin Apalin. Mereka bekerja di tempat Raja Kodali Melayu.

\section{4) Transformasi Tahap Kegemilangan}

Isantuk Paingko Arung akhirnya mampu mengumpulkan harta di negeri Jawa. la pulang membawa harta yang banyak bahkan ia membawa induk emas menyerupai bayi. Harta yang ia peroleh sebagai ganti harta yang sudah digunakanya untuk membayar adat perkawinan ketika menikahi Roronga Sonaru.

\section{5) Situasi Akhir}

Isantuk Paingko Arung hidup bahagia bersama kedua orang tuanya, isterinya dan dua anaknya.

Berdasarkan bagian-bagian dari struktur aktansial dan fungsional dari cerita Isantuk Paingko Arung, dapat dikelompokan sebagai berikut.

(1)Keinginan kakek menjadikan cucunya terkenal - mimpi menikah (pola 1)

(2)Menjalankan titah - menikah membayar adat perkawinan - harta habis (pola2)

(3) Keinginan mengganti harta mencari informasi (harta)- mencari jalan (pola 3)

(4) Melakukkan perjalanan - belajar menemukan pusat harta - bekerja (pola 4)

\section{Gaya Bahasa Cerita Isantuk Paingko Arung}

Berdasarkan hasil penelitian, gaya bahasa yang terdapat dalam cerita Isantuk Paingko Arung yaitu gaya bahasa yang jujur, sopan-santun dan menarik.

"Isantuk Paingko Arung merupakan seorang Raja bangsawan (samagat) di Sungai Apalin. Walaupun ia seorang raja, ia tidak memiliki kecakapan dibandingkan teman-teman seusianya. la tidak seperti Rambing, panglima perang suku Dayak Tamambaloh yang sangat sakti dan pemberani. Isantuk Paingko Arung hanyalah seorang raja biasa. Supaya Isantuk Paingko Arung menjadi populer seperti Rambing dan dikenang oleh keturunannya, maka alamahrum kakeknya meminta Isantuk Paingko Arung untuk menikahi Roronga Sonaru. Permintaan itu disampaikan lewat mimpinya Isantuk Paingko Arung. Atas titah kakeknya itu, Isantuk Paingko Arung menikahi Roronga Sonaru. Roronga Sonaru merupakan seorang dukun yang baru saja menjanda karena ditinggal mati oleh suaminya. Isantuk Paingko Arung pun akhirnya menikahi Rorongan Sonaru". 
Yudita Susanti dan Ursula Dwi Oktaviani. Baraa Nangis Isantuk ... Halaman $244-257$ Jurnal Belajar Bahasa, ISSN 2502-5864, E-ISSN 2503-0329

Volume 3, No. 2, September 2018

Berdasarkan penggalan sipnosis cerita di atas, gaya bahasa dalam cerita ini menunjukkan kejujuran, menceritakan keadaan atau fakta apa adanya kepada pembaca.

"Tiba di Selimbau, Isantuk Paingko Arung bertemu dengan Lotai Raja Cina. la belajar berhitung dan berdagang dari Lotai Raja Cina sampai ia mahir berhitung dan berdagang. Lama tinggal di Selimbau, mereka pun memutuskan untuk menemui Raja Sipang Batang Sintang di Sintang. Kedatangan mereka untuk meminjam kapal layar yang akan digunakan berlayar ke Jawa menemui Raja Kodali Melayu. Akan tetapi, rintangan pun muncul satu-persatu. Di sintang, Raja Sipang Batang Sintang tidak langsung memberikan kapalnya kepada Isantuk Paingko Arung. la meminta Isantuk Paingko Arung untuk bekerja dan membantunya selama berbulan-bulan. Sambil bekerja, Isantuk Paingko Arung belajar mengemudi kapal layar milik Raja Sipang Batang Sintang. la belajar mengemudi kapal dengan berdagang dari satu tempat ke tempat lainnya sampai ia mahir mengemudikan kapal. Keuletan dan kegigihan Isantuk Paingko Arung membuat Raja Sipang Batang Sintang semakin percaya dan mau meminjamkan kapal layar miliknya".

Gaya bahasa dalam penggalan cerita di atas menampilkan gaya bahasa yang sopan-santun. Pembaca diberikan penghargaan dengan kejelasan cerita.

"Sebelum melakukan perjalanan, tetua adat di sungai Apalin yang bernama Burung Pikin Apalin memanggil roh nenek moyang untuk menyertai mereka dalam perjalanan. Selain itu, Burung Pikin Apalin harus membunuh seeokor babi. Apabila hati babi tersebut bersih maka mereka Isantuk Paingko Arung boleh melakukan perjalanan, akan tetapi apabila hati babi tersebut rusak dan busuk maka mereka harus menunda perjalanan ke negeri Jawa, negeri Raja Kodali Melayu. Setelah babi itu dibunuh, hati babi itu bersih dan baik.

Setelah penentuan hari keberangkatan, Landook dan Ali-Ali Bua Basi memutuskan untuk mengajak Tingang, Aniyana, Isantuk Paingko Arung dan beberapa anak buahnya, Burung Kiung Balunus, pergi ke Jawa menemui Raja Kodali Melayu. Kedatangan mereka untuk bekerja di istana Raja Kodali Melayu. Hasil kerja tersebut akan diganti dengan harta benda milik Raja Kodali Melayu. Perjalanan panjang pun dimulai ketika baro dan isterinya, Isantuk Paingko Arung, beserta anak buahnya bertolak dari sungai Apalin. Baro-baro itu ada yang berjalan dan terbang dengan kecepatan angin sementara Isantuk Paingko Arung, Burung Kiung Balunus dan anak buah lainnya berangkat menggunakan perahu.

Gaya bahasa yang menarik ditemukan juga dalam penggalan cerita Isantuk Paingko Arung.Berdasarkan penggalan cerita di atas, ditemukan halhal menari seperti pemanggilan roh leluhur sebagai bentuk penyertaan dalam perjalanan, pertanda dari hewan yang dikurbankan, baro yang berjalan dan terbang dengan kecepatan angin. Hal-hal tersebut menjadi gaya bahasa yang menarik. 
Yudita Susanti dan Ursula Dwi Oktaviani. Baraa Nangis Isantuk ... Halaman $244-257$ Jurnal Belajar Bahasa, ISSN 2502-5864, E-ISSN 2503-0329

Volume 3, No. 2, September 2018

Berdasarkan analisis data tersebut, cerita Isantuk Paingko Arung memiliki gaya bahasa yang jujur, sopan-santun dan menarik.

Gaya bahasa struktur kalimat yang terdapat dalam cerita Isantuk Paningko Arung sebagai berikut.

\section{1) Repetisi}

Gaya bahasa repetisi adalah gaya bahasa pengulangan bunyi, kata dalam satu kalimat. Dalam cerita Isantuk Paingko Arung, struktur kalimat memiliki gaya bahasa repitisi. Berikut penjabaran gaya bahasa repitisi dalam cerita Isantuk Paingko Arung.

(1) Mauling lalo aso, mauling lalo malam, alao manyuliang.

(2) Sakule bua dapasang lita ling toan, ling lita ling banang.

(3) Kan sara sima, sara sima sasarina

(4) Aso minaak maniro, maniro serang

(5) Bulang maira kaian, kaian tindo ikin ira ulunku.

(6) Ajao lalo payo, payo korong soangin

(7) Baro ulu tali amas takolo malolong, malolong arayu.

(8) Tuli lao lolonga, lolong pakaina, lolong dawa lamba dai bolong pambeangiling mambonaga korong kabang baru, kabang baru dimbar.

(9) Imbar bea asoon, imbar anginangin, imbar ala-ala

(10) Dalola poang tarear mambangan baba sapat, baba pintu tindoan.

(11) Tabae bea asoon, tabae bea angin-angin.

(12) Unyi maunyi mansoangin.

(13) Dalenggang unyina kalong manggatana, kalong taroi mole.

Dari beberapa contoh di atas, gaya bahasa repetisi menjadi gaya bahasa yang dominan dalam cerita rakyat Isantuk Paingko Arung. Gaya bahasa repetisi terjadi pada pengulangan bunyi dan kata dalm satu struktur kalimat.

\section{2) Eponim}

Gaya bahasa eponim adalah gaya bahasa yang mengandung nama seseorang yang begitu sering dihubungkan dengan sifat tertentu sehingga nama itu dipakai untuk menyatakan sifat tertentu. Eponim dalam cerita Isantuk Paingko Arung dijabarkan dalam tabel berikut.

Tabel. EponimCeritalsantukPaingkoArung

\begin{tabular}{|c|c|c|c|}
\hline Nama & $\begin{array}{l}\text { Nama } \\
\text { Asli }\end{array}$ & Eponim & $\begin{array}{l}\text { Makna } \\
\text { Eponim }\end{array}$ \\
\hline $\begin{array}{l}\text { Isantuk } \\
\text { Paingko } \\
\text { Arung }\end{array}$ & Isantuk & $\begin{array}{l}\text { Paingko } \\
\text { Arung }\end{array}$ & $\begin{array}{l}\text { Orang yang } \\
\text { terakhir } \\
\text { diceritakan; } \\
\text { tidak ada } \\
\text { pengganti }\end{array}$ \\
\hline $\begin{array}{l}\text { Ali-Ali } \\
\text { Bua } \\
\text { Basi }\end{array}$ & Ali-Ali & $\begin{array}{l}\text { Bua } \\
\text { Basi }\end{array}$ & $\begin{array}{l}\text { Orang yang } \\
\text { sakti, kuat } \\
\text { dan berani }\end{array}$ \\
\hline $\begin{array}{l}\text { Burung } \\
\text { Pikin } \\
\text { Apalin }\end{array}$ & $\begin{array}{l}\text { Burung } \\
\text { Pikin }\end{array}$ & Apalin & Nama tempat \\
\hline $\begin{array}{l}\text { Lotai } \\
\text { Raja } \\
\text { Cina }\end{array}$ & Lotai & $\begin{array}{l}\text { Raja } \\
\text { Cina }\end{array}$ & $\begin{array}{l}\text { Nama } \\
\text { tempat, raja } \\
\text { di Cina }\end{array}$ \\
\hline $\begin{array}{l}\text { Raja } \\
\text { Sipang } \\
\text { Batang } \\
\text { Sintang }\end{array}$ & Sipang & $\begin{array}{l}\text { Batang } \\
\text { Sintang }\end{array}$ & $\begin{array}{l}\text { Sungai di } \\
\text { Sintang }\end{array}$ \\
\hline $\begin{array}{l}\text { Burung } \\
\text { Kiung } \\
\text { Balunus }\end{array}$ & $\begin{array}{l}\text { Burung } \\
\text { Kiung }\end{array}$ & Balunus & $\begin{array}{l}\text { Besar tinggi, } \\
\text { tegap, kekar. }\end{array}$ \\
\hline $\begin{array}{l}\text { Saladang } \\
\text { Ratu } \\
\text { Jawa }\end{array}$ & Saladang & $\begin{array}{l}\text { Ratu } \\
\text { Jawa }\end{array}$ & $\begin{array}{l}\text { Ratu yang } \\
\text { berkuasa di } \\
\text { Jawa }\end{array}$ \\
\hline $\begin{array}{l}\text { Raja } \\
\text { Timbul } \\
\text { Laut }\end{array}$ & Timbul & Laut & $\begin{array}{l}\text { Sungai yang } \\
\text { luas }\end{array}$ \\
\hline $\begin{array}{l}\text { Kodali } \\
\text { Raja } \\
\text { Melayu }\end{array}$ & Kodali & $\begin{array}{l}\text { Raja } \\
\text { Melayu }\end{array}$ & $\begin{array}{lr}\text { Raja } & \text { Melayu } \\
\text { di } & \text { negeri } \\
\text { Jawa. } & \\
\end{array}$ \\
\hline
\end{tabular}


Yudita Susanti dan Ursula Dwi Oktaviani. Baraa Nangis Isantuk ... Halaman $244-257$ Jurnal Belajar Bahasa, ISSN 2502-5864, E-ISSN 2503-0329

Volume 3, No. 2, September 2018

Berdasarkan analisis data pada tabel di atas, gaya bahasa eponim pada namanama tokoh dalam cerita Isantuk Paingko Arung dihubungkan dengan sifat dan nama tempat tertentu. Hal tersebut digunakan untuk menyatakan sifat dan tempat tertentu.

\section{KESIMPULAN}

Berdasarkan hasil analisis di atas, maka kesimpulan dalam penelitian ini sebagai berikut.

a) Cerita Isantuk Paingko Arung memiliki enam struktur aktansial. Aktan-aktan tersebut diisi oleh 1 pengirim (sender) yaitu keinginan kakek menjadikan cucunya terkenal; 5 penerima (recever) yaitu orang tua Isantuk Paingko Arung, Landook, AliAli Bua Basi, Tingang, Aniyana, Burung Kiung Balunus dan Mando; 1 objek (object) yaitu mencari harta ke negeri Jawa; 1 subjek (subject) yaitu Isantuk Paingko Arung; 13 penolong (helper) yaitu kakek, orang tua, Landook, Ali-Ali Bua Basi, Tingang, Aniyana, Burung Pikin Apalin, Lotai Raja Cina, Raja Sipang Batang Sintang, Saladang Ratu Jawa; dan 3 penentang (opponent) yaitu Raja Kodali Melayu, Raja Timbul Laut, dan Ratu Dadari.

b) Aktan terdiri atas tiga kategori yaitu manusia, baro (harimau siluman), dan benda mati (harta).

c) Struktur fungsional terdiri dari lima fungsi yaitu keinginan kakek menjadikan cucunya terkenal menjadi situasi awal; Isantuk Paingko Arung menikahi Roronga Sonaru kemudian hartanya menjadi habis menjadi tahap uji kecakapan; Isantuk Paingko Arung mencari harta ke negeri Jawa menjadi tahap utama; Isantuk Paingko Arung bertemu Raja Kodali Melayu dan mendapatkan harta yang banyak menjadi tahap kegemilangan; dan Isantuk Paingko Arung pulang ke sungai Apalin dan membawa harta berlimpah menjadi situasi akhir.

d) Gaya bahasa dalam baraa nangis Isantuk Paingko Arung yaitu jujur, sopan-santun, dan menarik. Sedangkan gaya bahasa berdasarkan struktur kalimat yang dominan muncul dalam cerita Isantuk Paingko Arung yaitu 13 gaya bahasa repitisi dan 9 gaya bahasa eponim.

\section{DAFTAR RUJUKAN}

Endraswara, S. (2009). Metodologi Penelitian Folklore. Yogyakarta: Media Pressindo.

Jabrohim. (1996). Pasar dalam Perspektif Greimas. Yogyakarta: Pustaka Pelajar. Jabrohim. (2003). Metodologi Penelitian Sastra. Yogyakarta: Hanindita Graha Widya.

Keraf, G. (2009). Diksi dan Gaya Bahasa. Jakarta: Gramedia Pustaka Utama.

Nirwana, Ade, Y. L., \& Mardi, A. A. (2015). Analisis Struktur Aktansial dan Fungsional dalam Voyage Au Centre De la Terre Karya Jules Verne. Jurnal IImu Budaya, 3 No. 2, 525-617.

Ratna, N. K. (2014). Teori, Metode dan Teknik Penelitian Sastra. Yogyakarta: Pustaka Pelajar. 
Yudita Susanti dan Ursula Dwi Oktaviani. Baraa Nangis Isantuk ... Halaman 244 - 257 Jurnal Belajar Bahasa, ISSN 2502-5864, E-ISSN 2503-0329

Volume 3, No. 2, September 2018

Susanto, D. (2012). Pengantar Teori Wellek, R., \& Warren, A. (2014). Teori Sastra. Yogyakarta: CAPS. Kesusastraan. Jakarta: Gramedia.

Teeuw, A. (2013). Sastra dan Ilmu Sastra. Wilpert, G. V. (1969). Sacghworterbuch Jakarta: Pustaka Jaya. de Literatur. Alfred Kroner Verlag. 